Bangladesh J. Bot. 39(2): 153-159, 2010 (December)

\title{
LIMNOLOGY OF LAKE BOGAKAIN, BANDARBAN, BANGLADESH
}

\section{Moniruzzaman KhondKer ${ }^{1}$, Md Almujaddade Alfasane, Mo Shafiqul Islam, M Azmal Hossain Bhuiyan and Md Ataul Gani}

\author{
Department of Botany, University of Dhaka, Dhaka-1000, Bangladesh
}

Key words: Bogakain, Limnology, Macrophyte, Phytoplankton, Bangladesh

\begin{abstract}
Bogakain, a natural high altitude (372 m) lake of Bangladesh has been limnologically investigated for the first time. At mid-point, the depth of the lake was measured $46.54 \mathrm{~m}$ and the Secchi visibility was $2.37 \mathrm{~m}$. Water temperature from 1-10 $\mathrm{m}$ depth gradient showed slight stratification in the lake which varied from 27.0 $-22.4^{\circ} \mathrm{C}$ at $1.00 \mathrm{pm} . \mathrm{pH}$ at the different depths ranged from $7.8-9.1$, conductivity from $75-80 \mu \mathrm{S} / \mathrm{cm}$ and TDS from $39-42 \mathrm{mg} / \mathrm{l}$. Alkalinity ranged from $0.8-1.24 \mathrm{meq} / \mathrm{l}$ and DO from $0.61-11.39 \mathrm{mg} / 1$. A total of 40 species of phytoplank-ton were recorded from the lake of which 21 belonged to Chlorophyceae followed by Cynaophyceae (5), Bacillariophyceae (4), Cryptophyceae (4), Euglenophyceae (3), Dinophyceae (2) and Chrysophyceae (1). Bloom by Synnechocystis salina Wisl was observed at $10 \mathrm{~m}$ depth. Water temperature correlated negatively and significantly with depth. Phytoplankton biomass as chl $a$ correlated positively with phytoplankton density and water depth. The former variable showed negative correlation with $\mathrm{pH}$ and water temperature. Lake Bogakain is the deepest natural lake of Bangladesh and many of the previous concepts regarding the lake i.e., fishless, highly turbid water and it has got a thermal spring at the bottom was found invalid.
\end{abstract}

\section{Introduction}

In Bangladesh nearly 7-8 million ha of wetlands do exist (Akonda 1989). These include rivers, haors, baors, ponds, beels, true lakes, man-made lakes, floodplains and reservoirs. Only three true lakes have been recognized in Bangladesh. These are Rainkyhongkine and Bogakain of Bandarban district and Ashulia Beel (though so called, is more properly a lake) of Dinajpur district (Khan et al. 1994, Rashid 1991). But, none of these lakes has been properly investigated from the limnological point of view except an algological report on Lake Rainkhyongkine by Islam and Uddin (1969). So, the present attempt was made to conduct a limnological investigation on Lake Bogakain.

\section{Materials and Methods}

The Bogakain (popularly known as Boga Lake) is a natural lake located at a height of $372 \mathrm{~m}$ above the mean sea level (Rashid 1991), on one of the plateau of the Politai Mountain Range at Naitong Mauza of Ruma upazila, district Bandarban and about $29 \mathrm{~km}$ east of the banks of the river Shankha. It is bounded on three sides by mountain peaks and thus given it a parallelogram or rectangular in shape and quite deep. There is no outlet from the lake and the basin is composed of the soft rocks of the Bhuban Formation. The main source of water is from the spring and also water from rainfall, surface drainage and seepage. The lake is situated at $21^{\circ} 58^{\prime} 49^{\prime \prime} \mathrm{N}$ and $92^{\circ} 28^{\prime} 11^{\prime \prime} \mathrm{E}$ and is approximately $500 \mathrm{~km}$ south-east of Dhaka city. It is believed that the lake is either the crater of an inactive mud volcano or it was originated due to falling of meteorites (Rahman and Chowdhury 2006). Some also argue in favor of a big landslide. It is venerated by the local Khumi tribes (Rahman and Chowdhury 2006, Rashid 1991, Khan et al. 1994). The lake is quite inaccessible because of bad communication.

${ }^{1}$ Corresponding author. $<$ mkhondker@yahoo.com> 
The present limnological expedition to Lake Bogakain was carried out on 10 March, 2010. The sampling was carried out in the mid point of the lake (Fig.1A) using a wooden boat from 1.00 - 3.00 p.m. The depth was measured by a graduated nylon rope. The Secchi visibility was measured by a Secchi disc of $20 \mathrm{~cm}$ in diameter. A 5 liter capacity Schindler's Sampler was used to record vertical water temperature profile, bottom water temperature (at $46.54 \mathrm{~m}$ ) and collection of water and phytoplankton samples at $1 \mathrm{~m}$ interval starting from surface to $10 \mathrm{~m}$ depth. Samples were stored in $500 \mathrm{ml}$ capacity plastic screw capped bottles containing Lugol's iodine. Simultaneously, the rest of the water sample was used to measure conductivity, TDS and $\mathrm{pH}$ in situ by using respective field meters (HANNA Instruments HI 9033, 9044 and). Ten BOD bottles (Pyrex, UK) were filled with sample water from each depth of the lake and fixed in situ for DO analysis. The sampling was completed at 15:00 $\mathrm{h}$ and all the collected samples were transported in a Cool Box to Limnology and Hydrobiology Laboratory, Department of Botany, University of Dhaka and analyzed immediately (after 16 - 18 hours of collection).

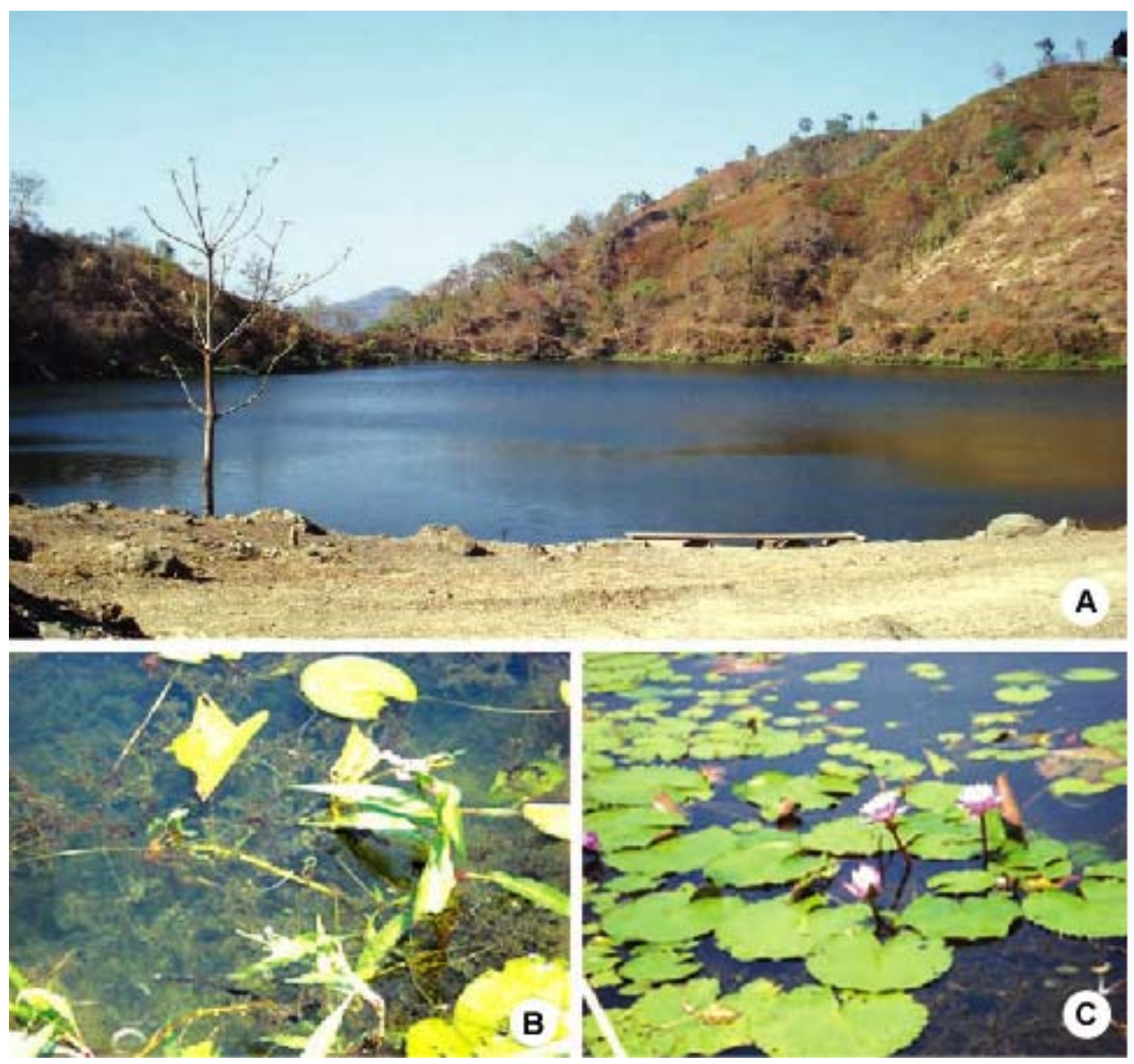

Figs 1A-C: A. Open water of Lake Bogakain. B. Polygonum sp. (foreground), submerged Egeria densa Planchón and parts of floating hydrophytes. C. Nymphaea pubescens Willd.

Chlorophyll $a$ (chl $a$ ), soluble reactive phosphorus (SRP), soluble reactive silicate (SRS), dissolved oxygen (DO) and alkalinity were determined on the same day (Marker et al. 1980, Murphy and Riley 1962, Wetzel and Likens 1979). However, an overnight digestion of samples 
for nitrate nitrogen analysis (Müller and Wiedemann 1955) was carried out. Phytoplankton cell number were counted using a Hawksley microplankton counting chamber with improved Neubauer Rulling (Hawksley Ltd., Lancing, England) under a Nikon compound microscope (Japan) at a magnification of $400 \times$.

\section{Results and Discussion}

The lake water looked sky blue in a sunny weather. At mid-point, the depth of the lake was measured $46.54 \mathrm{~m}$ and the Secchi visibility was $2.37 \mathrm{~m}$. All other physicochemical data have been presented in Table 1. Air temperature was $33.0^{\circ} \mathrm{C}$, surface and bottom water temperatures were 27.0 and $22.2^{\circ} \mathrm{C}$, respectively. Water temperature at $1-10 \mathrm{~m}$ depths gradient showed slight stratification in the lake which varied from $22.3-27.0^{\circ} \mathrm{C}$ (Table 1). $\mathrm{pH}$ at different depths ranged from $7.8-9.1$, conductivity from $75-80 \mu \mathrm{S} / \mathrm{cm}$ and TDS from $39-42 \mathrm{mg} / \mathrm{l}$. Whereas, the alkalinity ranged from $0.8-1.24 \mathrm{meq} / \mathrm{l}$ and $\mathrm{DO}$ from $0.61-11.39 \mathrm{mg} / \mathrm{l}$ (Table 1). The SRP and $\mathrm{NO}_{3}-\mathrm{N}$ concentrations in the first meter of water depths were very high such as $154.32 \mu \mathrm{g} / \mathrm{l}$ and $24.73 \mathrm{mg} / \mathrm{l}$, respectively (Table 1). While, at $2-10 \mathrm{~m}$ depths were $41.85-87.95 \mu \mathrm{g} / \mathrm{l}$ and $0-1.4$ $\mathrm{mg} / \mathrm{l}$, respectively. But at $3-4$ and $6-9 \mathrm{~m}$ of water depths no detectable $\mathrm{NO}_{3}-\mathrm{N}$ was recorded.

Table 1. Physical, chemical and biological features of water in Lake Bogakain.

\begin{tabular}{cccccccccccccc}
\hline $\begin{array}{c}\mathrm{Z} \\
(\mathrm{m})\end{array}$ & $\begin{array}{c}\text { Temp. } \\
\left({ }^{\circ} \mathrm{C}\right)\end{array}$ & $\mathrm{pH}$ & $\begin{array}{c}\text { Cond. } \\
(\mu \mathrm{S} / \mathrm{cm})\end{array}$ & $\begin{array}{c}\text { TDS } \\
(\mathrm{mg} / \mathrm{l})\end{array}$ & $\begin{array}{c}\text { Alkal. } \\
(\mathrm{meq} / \mathrm{l})\end{array}$ & $\begin{array}{c}\mathrm{DO} \\
(\mathrm{mg} / \mathrm{l})\end{array}$ & $\begin{array}{c}\mathrm{SRP} \\
(\mu \mathrm{g} / \mathrm{l})\end{array}$ & $\begin{array}{c}\text { SRS } \\
(\mathrm{mg} / \mathrm{l})\end{array}$ & $\begin{array}{c}\mathrm{NO}_{3} \text {-N } \\
(\mathrm{mg} / \mathrm{l})\end{array}$ & $\begin{array}{c}\text { Phaeo. } \\
(\mu \mathrm{g} / \mathrm{l})\end{array}$ & $\begin{array}{c}\text { Chl } a \\
(\mu \mathrm{g} / \mathrm{l})\end{array}$ & $\begin{array}{c}\text { Cell density } \\
\times 10^{3} / 1\end{array}$ \\
\hline 1 & 27.0 & 9.1 & 75 & 39 & 0.88 & 8.54 & 154.32 & 0.36 & 24.73 & 2.59 & 2.96 & 686.62 \\
2 & 26.6 & 9.0 & 78 & 41 & 1.04 & 11.18 & 59.21 & 0.23 & 1.4 & 3.68 & 3.95 & 890.70 \\
3 & 26.3 & 9.1 & 80 & 41 & 0.96 & 11.18 & 50.10 & 0.56 & 0 & 0.32 & 5.92 & 2445.86 \\
4 & 25.2 & 9.1 & 77 & 40 & 1.18 & 11.39 & 53.92 & 0.69 & 0 & 2.51 & 7.89 & 2211.46 \\
5 & 24.2 & 8.2 & 76 & 40 & 0.9 & 6.50 & 61.85 & 0.16 & 0.6 & 1.15 & 14.80 & 1433.12 \\
6 & 23.8 & 8.1 & 75 & 41 & 0.88 & 3.87 & 87.97 & 0.62 & 0 & 4.99 & 8.88 & 25837.80 \\
7 & 22.5 & 8.2 & 78 & 42 & 0.96 & 1.43 & 68.60 & 0.59 & 0 & 7.76 & 8.88 & 2601.78 \\
8 & 22.3 & 7.9 & 79 & 41 & 1.24 & 0.61 & 64.49 & 0.59 & 0 & 8.16 & 9.87 & 1919.23 \\
9 & 22.5 & 7.9 & 74 & 41 & 0.88 & 1.63 & 41.85 & 0.39 & 0 & 3.99 & 9.87 & 3256.05 \\
10 & 22.4 & 7.8 & 78 & 39 & 0.94 & 1.22 & 51.58 & 0.43 & 0.1 & 2.35 & 43.41 & 409381.73 \\
\hline
\end{tabular}

Silicate concentration ranged from $0.41-0.69 \mathrm{mg} / \mathrm{l}$ at $1-10 \mathrm{~m}$ depths. Chl $a$ concentration was higher at 5 and $10 \mathrm{~m}$ depths of the lake. Values recorded in this two depths were 14.80 and $43.41 \mu \mathrm{g} / \mathrm{l}$, respectively. At other depths, chl $a$ varied from $2.96-9.87 \mu \mathrm{g} / 1$ being the lowest record at $1 \mathrm{~m}$ depth. In lake Anibal of Brazil seasonal maxima of Chl $a$ occurred from 6-14 m (Reynolds 1997). Phaeopigment showed a range of $0.32-8.16 \mu \mathrm{g} / \mathrm{l}$, while the highest at $8 \mathrm{~m}$ and lowest at $3 \mathrm{~m}$ depth of water (Table 1). Phytoplankton total density varied from 686.62 $409381.73 \times 10^{3} \mathrm{ind} / \mathrm{l}$, the highest being for Synnechocystis salina only at $10 \mathrm{~m}$ depth. The second longest taxon was Trachelomonas volvocina.

A total of 40 species of phytoplankton from pelagic zone of the lake were recorded. The highest density occurred at $10 \mathrm{~m}$ depth, contributed by unicellular cyanobacteria, Synechocystis salina Wisl (Table 2), which formed bloom with a cell count $406247.98 \times 10^{3}$ cells/l. It is to be noted that $S$. salina did not occur at other depths of the lake. Formation of metalimnetic plates by cyanobacteria has also been observed in some lakes of Brazil (Reynolds 1997). Light, hydrological stability and chemical gradients were found responsible for that. The lowest density of phytoplankton occurred at $1 \mathrm{~m}$ depth (Table 2). Dinobryon divergens Imhof, Cyclotella comensis Grun. and Peridinium lomnicki Wolosz. were present at all depths. Among subdominant 


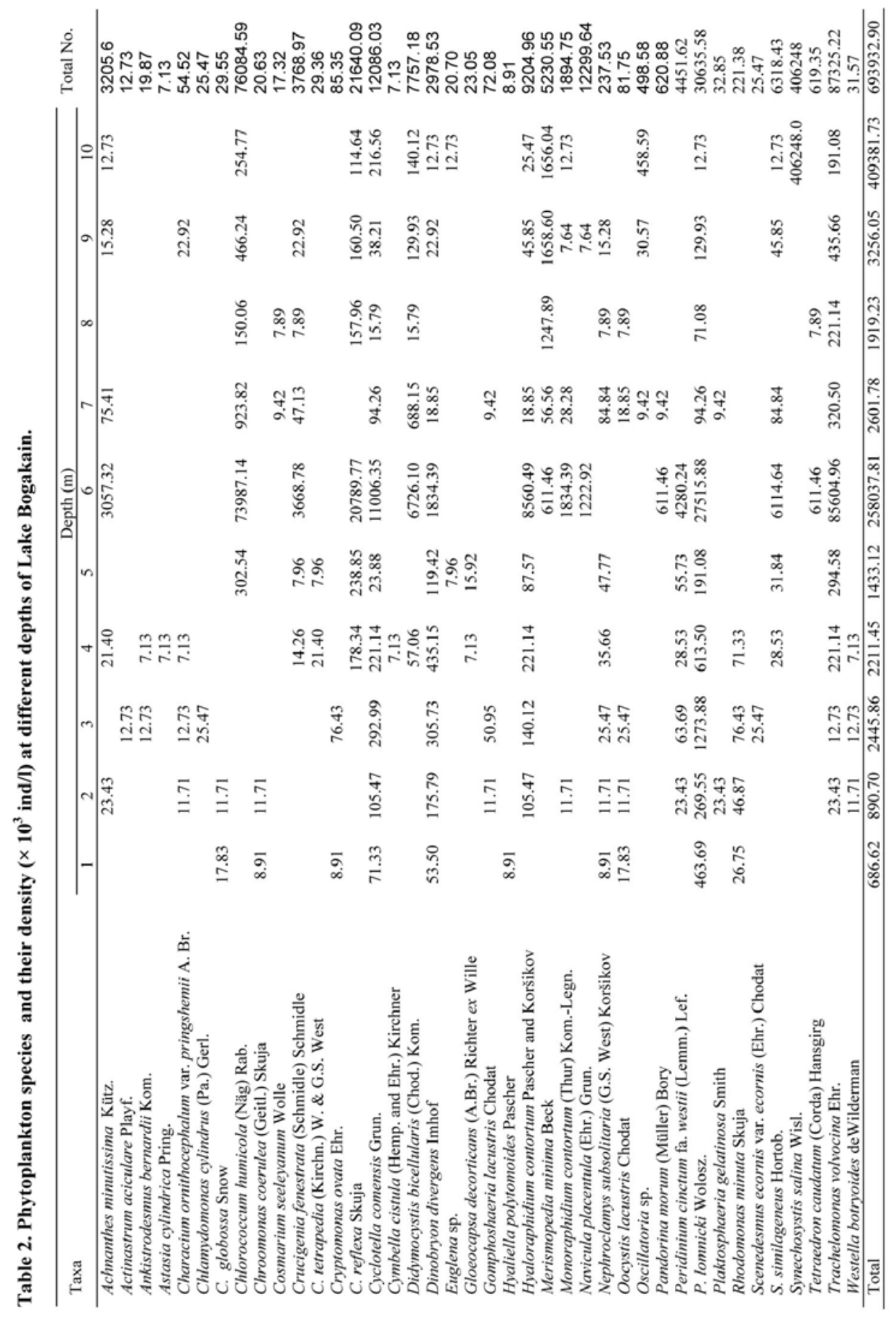


species of phytoplankton, Chlorococcum humicola (Näg.) Rab., Crucigenia fenestrata (Schmiddle) Schmiddle, Cryptomonas reflexa Skuja, Didymocystis bicellularis (Chod.) Kom., Hyaloraphidium contortum Pascher and Koršikov, Merismopedia minima Beck, Nephrochlamys subsolitaria (G.S. West) Koršikov, Scenedesmus similageneus Hortob. and Trachelomonas volvocina Ehr. mostly showed their occurrence until $10 \mathrm{~m}$ depth (Table 2). Highest number of species was recorded from algal class Chlorophyceae followed by Cyanophyceae, Bacillariophyceae, Cryptophyceae, Dinophyceae and Chrysophyceae (Table 3). The proportion (\%) of recorded species under Cyanophyceae and Chlorophyceae in both Bogakain and Kaptai Lake is almost closer to each other except member of Bacillariophyceae where diversity is lower in Lake Bogakain (Table 3). However, the total number of taxa recorded in Lake Bogakain is nearly half than those recorded for Kaptai Reservoir (Bogakain, 40 taxa; Kaptai Lake, 81 taxa of phytoplankton) and this is due to the higher number of greens and diatoms. Lower $\mathrm{PO}_{4}-\mathrm{P}$ concentration in the former lake than the latter might be the reason for this (Table 4).

Table 3. Number of species of different classes of phytoplankton from Bogakain and Kaptai Lake, a comparison.

\begin{tabular}{lcccccc}
\hline \multirow{2}{*}{ Classes } & \multicolumn{2}{c}{ Recorded species } & & \multicolumn{2}{c}{ Percentage of the total } \\
\cline { 2 - 3 } \cline { 5 - 6 } & Bogakain & Kaptai $\dagger$ & & Bogakain & Kaptai $\dagger$ \\
\hline Cyanophyceae & 5 & 11 & & 12.5 & 13.5 \\
Chlorophyceae & 21 & 42 & & 52.50 & 51.9 \\
Euglenophyceae & 3 & 2 & & 7.5 & 2.5 \\
Bacillariophyceae & 4 & 22 & & 10.0 & 27.2 \\
Cryptophyceae & 4 & 1 & & 10.0 & 1.2 \\
Dinophyceae & 2 & 2 & & 5.0 & 2.5 \\
Chrysophyceae & 1 & 1 & & 2.5 & 1.2 \\
\hline
\end{tabular}

$\dagger$ Hydrobiology of the Kaptai Reservoir. FAO/UNDP Contract No. DP/BGD/79/O15-4/FI, February, 1986, 21 pp.

Table 4. A comparison of Bogakain and Kaptai lakes from hill districts of Bangladesh.

\begin{tabular}{|c|c|c|}
\hline Parameters & Lake Bogakain & $\begin{array}{c}\text { Kaptai lake } \\
\text { (Chowdhury and Mazumder 1981)* }\end{array}$ \\
\hline GIS & $21^{\circ} 58^{\prime} 49^{\prime \prime} \mathrm{N}$ and $92^{\circ} 28^{\prime} 11^{\prime \prime} \mathrm{E}$ & $22^{\circ} 29^{\prime} \mathrm{N}$ and $92^{\circ} 17^{\prime} \mathrm{E}$ \\
\hline Altitude (m) & 372 & 31.1 \\
\hline Area (ha) & $8-9$ & 583 \\
\hline $\mathrm{Z}_{\max }(\mathrm{m})$ & 46.54 & 32 \\
\hline $\mathrm{Zs}(\mathrm{m})$ & 2.37 & 3.29 \\
\hline Water temp. $\left({ }^{\circ} \mathrm{C}\right)$ & 27.5 & 26.0 \\
\hline TDS (mg/l) & 39 & 76 \\
\hline Conductivity $(\mu \mathrm{S} / \mathrm{cm})$ & 75 & 114 \\
\hline $\mathrm{pH}$ & 9.1 & 6.30 \\
\hline Alkalinity (meq/l) & 0.88 & 0.80 \\
\hline $\mathrm{DO}(\mathrm{mg} / \mathrm{l})$ & 8.54 & 6.25 \\
\hline $\mathrm{PO}_{4}-\mathrm{P}(\mu \mathrm{g} / \mathrm{l})$ & 154.32 & 830 \\
\hline $\mathrm{NO}_{3}-\mathrm{N}(\mathrm{mg} / \mathrm{l})$ & 24.73 & 10.5 \\
\hline
\end{tabular}

* Extrapolated for March value for surface water. 
Correlation analysis among the recorded variables vs depths $(1-10 \mathrm{~m}, \mathrm{n}=10$, one sample from each depth) showed significant positive correlation between chl $a$ vs phytoplankton density (Table 5). Highly negative correlation between depth vs water temperature strongly suggests thermally stratified lake. Depth vs chl $a$ showed a significant positive correlation, while water temperature vs chl $a$ shows a negative correlation. Chl $a$ vs $\mathrm{pH}$ was negatively correlated. Relationships between chl $a$ and all other variables were negative but insignificant (Table 5).

Table 5. Results of correlation analyses between parameters relating physical, chemical and biological factors. $^{1}$

\begin{tabular}{|c|c|c|c|}
\hline $\begin{array}{l}\text { Independent variable } \\
\text { (x) }\end{array}$ & $\begin{array}{c}\text { Dependent variable } \\
(\mathrm{y})\end{array}$ & $\begin{array}{l}\text { Correlation } \\
\text { coefficient (r) }\end{array}$ & Probability \\
\hline Phytoplankton density (ind/l) & Chlorophyll $a(\mu \mathrm{g} / 1)$ & 0.958 & $\mathrm{p}<0.01$ \\
\hline Phytoplankton density (ind/l) & Phaeopigment concentration $(\mu \mathrm{g} / \mathrm{l})$ & -0.179 & ns \\
\hline $\mathrm{NO}_{3}-\mathrm{N}(\mathrm{mg} / \mathrm{l})$ & Phytoplankton density (ind/l) & -0.128 & ns \\
\hline $\mathrm{SRP}(\mu \mathrm{g} / 1)$ & Chlorophyll $a(\mu \mathrm{g} / \mathrm{l})$ & -0.316 & ns \\
\hline Dissolved oxygen (DO) (mg/l) & Chlorophyll $a$ " & -0.475 & ns \\
\hline Alkalinity $(\mathrm{meq} / \mathrm{l})$ & Chlorophyll $a \quad "$ & -0.126 & ns \\
\hline Total dissolved solids $(\mathrm{mg} / \mathrm{l})$ & Chlorophyll $a \quad "$ & -0.474 & ns \\
\hline Conductivity $(\mu \mathrm{S} / \mathrm{cm})$ & Chlorophyll $a \quad "$ & 0.126 & ns \\
\hline $\mathrm{pH}$ & Chlorophyll $a \quad "$ & -0.574 & ns \\
\hline Water temperature $\left({ }^{\circ} \mathrm{C}\right)$ & Chlorophyll $a$ " & -0.526 & ns \\
\hline Water depth $(\mathrm{m})$ & Chlorophyll $a \quad "$ & 0.665 & $\mathrm{p}<0.05$ \\
\hline Water depth (m) & Water temperature $\left({ }^{\circ} \mathrm{C}\right)$ & -0.963 & $\mathrm{p}<0.01$ \\
\hline SRS $(\mathrm{mg} / \mathrm{l})$ & Chlorophyll $a(\mu \mathrm{g} / \mathrm{l})$ & -0.087 & ns \\
\hline $\mathrm{NO}_{3}-\mathrm{N}(\mathrm{mg} / \mathrm{l})$ & Dissolved oxygen $(\mathrm{mg} / \mathrm{l})$ & 0.241 & ns \\
\hline
\end{tabular}

${ }^{1} \mathrm{n}=10, \mathrm{~ns}=$ not significant.

Rahman and Chowdhury (2006) mentioned the lake as $38 \mathrm{~m}$ deep, acidic and having hot spring at its bottom and due to the discharge of that hot spring the water colour of the lake changes sometimes as highly turbid. But during the present study on 10 March 2010 these features were not found. Again, Rahman and Chowdhury (2006) reported that 'it is fishless and no weed and plant can grow there'. But the lake has a vast littoral area occupied by a number of aquatic macrophytes like Nymphaea nouchali Brum.f., Egeria densa Planch. (Alfasane et al. 2010), Potamogeton crispus L., Polygonum sp., etc. (Fig. 1 B-C) and 40 species of pelagic phytoplankton. The lake is also invaded by Oreochromis mossambicus (Peters) and Channa marulius (Hamilton) (personal communication). During the present investigation some small fishes and angling by local people were found.

A comparative analysis of physiographic, morphometric and limnological data for Bogakain and Kaptai Lakes is shown in Table 4. Both the lakes are similar in many respect except a high value of $830 \mu \mathrm{g} / \mathrm{I} \mathrm{PO}_{4}-\mathrm{P}$ (Chowdhury and Mazumder 1981). But an unpublished result showed the value as $530 \mu \mathrm{g} / \mathrm{l}$ in Kaptai lake. The high value of $\mathrm{PO}_{4}-\mathrm{P}$ (SRP) in Kaptai lake appeared to be due to anthropogenic factors. The $\mathrm{NO}_{3}-\mathrm{N}$ value for Bogakain is little more than double of that from Kaptai Lake (Table 4). Kaptai Lake is a manmade reservoir type, where the only hydroelectric power plant of the country is located. On the other hand, Bogakain is considered to be a high altitude, deepest, natural lake of Bangladesh. Compared to area, Kaptai Lake is much bigger than Bogakain. Zs, TDS and conductivity in Kaptai lake is little higher than Bogakain while water temperature and alkalinity of both the lakes are found same for the month of March (Table 4). 
It appears that the Lake Bogakain is a thermally stratified (at summer) eutrophic lake. The lake is quite interesting from the limnological perspective and should be investigated thoroughly.

\section{Acknowledgements}

The authors are indebted to Professor Dr Md Abul Hassan, Chairman, Department of Botany, University of Dhaka for his encouragement to carry out the expedition. Necessary support extended by Md Amjad Hossain, District Commandant, Ansar and VDP, Bandarban to visit the Boga lake is gratefully acknowledged.

\section{References}

Akonda AW 1989. Bangladesh. In: A directory of Asian Wetlands, Scott DA (Ed), pp. 541-581. IUCN, Switzerland and Cambridge.

Alfasane MA, M Khondker, MS Islam and MH Bhuiyan 2010. Egeria densa Planchón (Hydrocharitaceae): A new angiospermic record for Bangladesh. Bangladesh J. Plant Taxon. 17(2): 209-213.

Chowdhury SH and A Mazumder 1981. Limnology of Lake Kaptai. I. Physico-chemical features. Bangladesh J. Zool. 9(1): 59-72.

Islam AKMN and MA Uddin 1969. A preliminary report on the phytoplankton and other algae of Chittagong Hill-Tracts. J. Asiat. Soc. Pak. 14(3): 353-363+13 pls.

Khan MS, E Haq, S Huq, AA Rahman, SMA Rashid and H Ahmed (Eds) 1994. Wetlands of Bangladesh. BCAS, Dhaka. 91 pp.

Mackereth FJH, J Heron and JF Talling 1978. Water analysis: some revised methods for limnologists. Freshwater Biol. Assoc. Pub. No. 36, 120 pp.

Marker AFH, EA Nusch, H Rai and B Riemann 1980. The measurement of photosynthetic pigments in freshwaters and standardization of methods: conclusions and recommendations. Archiv für Hydrobiologiie Ergebnisse der Limnologie 14: 91-106.

Müller R and F Wiedemann 1955. Die Bestimmung des Nitrats in Wasser. Jahrb. Wasserchem. Wasserreinigungstechnik. Verlag Chimie 12: 247-271.

Murphy J and JP Riley 1962. A modified single solution method for the determination of phosphate in natural waters. Anal. Chim. Acta 27: 31-36.

Rahman SMM and SQ Chowdhury 2006. Bagakain Lake. In: Banglapedia, Islam S (Ed), pp. 360-361. Asiat. Soc. Bangladesh, Dhaka.

Reynolds CS 1997. On the vertical distribution of phytoplankton in the Middle Rio Doce Vale lakes. In: Limnological Studies on the Rio Doce Valley Lakes, Brazil, Tundisi J.G. and S. Yatsuka (Eds), pp. 227241. Brazilian Acad. Sci., Univ. S. Paulo, Brazil.

Rashid H Er 1991. Geography of Bangladesh. Univ. Press Ltd. Dhaka. 529 pp.

Wetzel RG and GE Likens 1979. Limnological analysis. WB Saunders Co., Philadelphia. 357 pp. 